which will be read with nostalgia by those familiar with this part of Africa, and which will long live to give genuine pleasure to a much wider public.

\title{
H. B. C.
}

Wildlife Conservation. By Ira N. Gabrielson. Second Edition. The Macmillan Company, New York. \$5.50.

Whether we like it or not, and some of us like it little, conservation of natural resources for the use of man, including conservation of wild life, has come to take the place of simple preservation. If we try merely to protect wild animals from man, we shall be beaten by the hard fact of spreading humanity and increasing populations. Moreover, if we are beaten in our task of nature conservation, then not only will wild animals disappear but plants, water, and soil will in many places be irreparably damaged. In this book, Dr. Gabrielson convincingly shows us that all are inextricably woven together into a beautiful pattern for the benefit of each. This unity is indeed his theme but he necessarily separates the constituents of conservation, dealing separately with soil, water, forests, grasslands, and wild life. Wild life again he sub-divides into game, other birds and mammals, fur animals, migratory birds, and vanishing species. Chapters are devoted to predator relationships, wildlife refuges and the obstacles to conservation.

The book is related entirely to America where Dr. Gabrielson was Director of the United States Fish and Wildlife Services until his retirement in $\mathbf{1 9 4 6}$ to become President of the Wildlife Management Institute. So, though very conscious of the beauty of living things, Dr. Gabrielson is a practical man who deals with his subject in an unsentimental way, and wisely so-though I wish that in his chapter " Life of the Waters" he could have felt moved to condemn what to me seems abominable, the practice of poisoning all fish in a lake, so that they may be replaced by those game fish which the angler prefers.

In stressing the need for management of wild life even within sanctuaries, Dr. Gabrielson mentions the deer of the Kaibab which is the classic example of the destruction of a habitat through over-protection of herbivorous animals, but he might $I$ think have pointed out that before Kaibab was made a reserve there was a Government campaign to destroy. all carnivores, and in eighteen years 674 pumas, 3,000 coyotes and many wild cats were killed. No wonder the deer became unmanageable !

Dr. Gabrielson tells us that in the United States all state wild 
life organizations are financed entirely by licence fees from hunting and fishing - a solution often put forward for all the financial troubles of wild life preservation. He points out a serious disadvantage-wild life administrators are under constant pressure to provide more and more animals of the particular kind which sportsmen want to kill. It is very difficult for those administrators to follow constructive conservation programmes including conservation of fur-bearing predators-foxes, wild cats, pumas, and bears. Another disadvantage of this policy is that when wild life becomes scarce and most money is needed to preserve it, least is likely to be available.

Finally Dr. Gabrielson describes America's huge Federal marsh and lake restoration programme. Twenty thousand square miles is the minimum which is contemplated, and half this is completed or under way. This brings to mind the fight that failed to prevent the draining of Malheur Lake in Oregon so that T. Gilbert Pearson could write in his autobiography Adventures in Bird Protection, "No wild life was left. The earth was baked and cracked and burnt ; in the alkali dust curled the whitened forms of fish, and the horns and heads of long dead bison came to view. Malheur the Wonderful had become Gehenna, the Place of Death. Now and then a wandering gull flew by with a discordant cry. The greatest area for water birds in all our vast Western country was no more." But in 1934 restoration began and Dr. Gabrielson tells us that Malheur's wide expanses soon attracted back every species of bird known to nest there before the destruction when "the friends of the birds were too few to withstand the combined attacks of politics and commercialism."

$$
\text { C. L. B. }
$$

The Kingdom of the Octopus : the Life History of the Cephalopoda. By Frank W. Lane. Jarrolds, London, 1957, 30s. : Sheridan House, New York, 1960, $\$ 7.50$.

This is the first popular book to appear on this subject since Henry Lee wrote his delightful The Octopus or the "devil-fish" of fact and of fiction in $\mathbf{1 8 7 5}$. This is a worthy successor which takes note of the tremendous advances since those days when the gigantic squids of the North Atlantic were only just beginning to attract the attention of scientists and the seas were also beginning to yield rich collections of cephalopods of all kinds to the great expeditions.

Mr. Lane has gone a long way towards satisfying popular 